\section{Olga Boginskaya}

Irkutsk National Research Technical University,

Russian Federation
2021, Vol. 18 (2), 31-49(230)

revije.ff.uni-lj.si/elope

https://doi.org/10.4312/elope.18.2.31-49

UDC: 81'362:[81'25:34]

\title{
A Contrastive Study of Deontic Modality in Parallel Texts
}

\begin{abstract}
This article is a contrastive study of deontic modal markers in three parallel texts. It analyses the modality system in the English, Russian and French texts of the Universal Declaration of Human Rights accounting for the ambiguity of some English modal verbs in legal texts and the difficulty in rendering them into a different language. The research reveals modal markers used to express deontic permission, deontic obligation and deontic prohibition in the three parallel texts; semantic similarities and discrepancies between these modal markers; and translation strategies employed to render the English modal markers into Russian and French. The article responds to the need for a systematic analysis of deontic modal markers in English, Russian and French due to the semantic and syntactic differences among the German, Romance and Slavic languages. The article concludes that French and Russian have more in common than French and English or Russian and English in terms of the deontic modality.
\end{abstract}

Keywords: deontic modality, legal text, modal marker, legal translation

\section{Protistavna študija deontične modalnosti v vzporednih besedilih}

\section{IZVLEČEK}

$\mathrm{V}$ članku se osredinjamo na protistavno študijo deontičnih modalnih označevalcev $\mathrm{v}$ treh vzporednih besedilih. Analiziramo sistem modalnosti v angleških, ruskih in francoskih besedilih Splošne deklaracije o človekovih pravicah, pri čemer upoštevamo dvoumnost nekaterih angleških modalnih glagolov $\mathrm{v}$ pravnih besedilih in težave pri njihovem prevajanju v drug jezik. V raziskavi razkrivamo modalne označevalce, ki se uporabljajo za izražanje dovoljenja, obveznosti in prepovedi $v$ treh vzporednih besedilih; semantične podobnosti in neskladja med temi modalnimi označevalci; in prevajalske strategije, uporabljene za prevajanje angleških modalnih označevalcev v ruščino in francoščino. Sistematična analiza deontičnih modalnih označevalcev v angleščini, ruščini in francoščini je zaradi pomenskih in skladenjskih razlik med nemškim, romanskim in slovanskim jezikom nujno potrebna. V članku ugotavljamo, da imata francoščina in ruščina več skupnega kot francoščina in angleščina ali ruščina in angleščina glede deontične modalnosti.

Ključne besede: deontična modalnost, pravno besedilo, modalni označevalec, pravni prevod 


\section{Introduction}

The translation of international legal documents as a complex process involving different semiotic systems is one of the components of international relations. Legal texts which are regulative by nature have to inform about the law and prescribe some behaviours. These functions "must be rendered unambiguously in translating through the relevant linguistic realization patterns (performatives, modal verbs, lexical verbs)" (Trosborg 1997, 157). The legal language involves a large number of prescriptive sentences which convey directives, standards, rights, obligations, and prohibitions. The frequent use of modal markers is the feature that differs legal discourse from other types of discourses (Boginskaya 2020; Krapivkina 2017; Trosborg 1997).

A comparison of languages by their lexical and grammatical structures, in terms of configuration and intersection of application areas, is important for their study. Assessment of the degree of reliability of events is one of the main qualities of human existence and knowledge of the world.

Modality is a linguistic feature of any text, being a source of considerable difficulty for interpreters due to the subtle and complex nature of the meanings modals convey (Tiersma 1999; Bhatia and Bhatia 2011; Foley 2001; Garner 1995; Mellinkoff 1963; Mattila 2013). However, semantic discrepancies between the modal markers in English, French and Russian have been barely treated from the contrastive perspective. Thus, the main objective of this article is to carry out a contrastive analysis of modal markers as tools employed to express deontic modality in the three parallel legal texts in order to identify similarities and discrepancies between the English, French and Russian versions of this international document from the perspective of deontic modality expression. To achieve this objective, the research seeks answers to the following questions:

RQ1: What modal markers are used to express deontic permission, deontic obligation and deontic prohibition in the three parallel texts?

RQ2: Are there any similarities and discrepancies between the modal markers in the three parallel texts?

RQ3: What translation strategies are used to render the English modal markers into Russian and French?

A contrastive analysis of the English, French and Russian versions of the international legal document will provide evidence of difficulties in mediating among three languages.

The next part of the article sets the theoretical framework for the study. In Part 3, the methods employed to analyse the data are shown and the materials are described. Part 4 is devoted to the findings of the current study, including some examples of each function of the modal marker. The key findings are discussed in Part 5, while the final part provides a brief overview of the conclusions of the study. 


\section{Theoretical Framework}

\subsection{Deontic Modality}

In Systemic Functional Linguistics, language is considered to be a semantic system performing three functions: ideational, interpersonal and textual. The interpersonal function deals with the use of language to establish and maintain relationships with other people, to influence their behaviour, or to express one's own viewpoints. It is implemented through the mood and modality systems. The modality system, which is the focus of the present study, expresses the speaker's attitudes and judgments and reflects their assessments of the validity of propositions. The category of modality is built on the communicative-evaluative aspect whose linguistic development has a well-established tradition. Along with changes in scientific paradigms, the aspects of studies of modality have changed as well. However, most authors agree that modality belongs to the main language categories (e.g., Quirk et al. 1989). It expresses different types of relations between the utterance and reality, as well as different types of subjective qualifications of what is communicated, and "may be defined as the manner in which the meaning of a clause is qualified so as to reflect the speaker's judgment of the likelihood of the proposition it expresses being true" (Quirk et al. 1989, 219).

In the linguistics literature (Halliday 1978; Lyons 1977; Bybee, Perkins, and Pagliuca 1994), three types of modality are distinguished: epistemic (modes of knowing), deontic (modes of obligation), and alethic (modes of truth). Alethic modality expresses the necessary truth of a proposition (Lyons 1977), epistemic modality expresses knowledge of an entity or an event, and deontic modality expresses permission or obligation (Lyons 1977; Palmer 2001, 2013).

The term deontic modality comes from the Greek word $\delta \varepsilon$ cov, $\delta \varepsilon o v \tau o \varsigma$ ('duty'). Deontic modality means that the speaker "intervene[s] in the speech event by laying obligations or giving permission" (Downing and Locke 1992, 382); it conveys the idea that it is necessary for someone to do something (Depraetere and Langford 2020, 273; Panocová and Lukačín 2019). Lyons $(1977,823)$ claims that "[w]hen we impose upon someone the obligation to perform or to refrain from performing a particular act," we are describing "the state-of-affairs that will obtain if the act in question is performed" rather than his performance of that act.

The key exponents of modality are a set of modal markers that create a modal system (Palmer 2003, 2). In German, Slavic and Romance languages, the principal members of this system are modal verbs. Such verbs are typically used with other main verbs "to make an assessment, judgment or interpretation of what we are speaking or writing about, or express our attitude to this" (Parrott 2000, 152). Alongside the modal verbs are other markers (lexical modals) capable of conveying modal meanings.

\subsection{Legal Discourse and Modality}

According to Tiersma (1999), "legal language" is a sublanguage rather than a language distinct from General English, and is varied in response to different cultural contexts.

Studies show that besides the commonly recognized features of legal texts, such as legal terminology, Latinisms and archaic words, there are other lexical and syntactic features that are 
characteristic of legal language: complex prepositions (hereinafter, hereof); modal verbs (e.g., shall); proper nouns denoting names for institutions, state bodies, titles; nominalizations; doublets (null and void, will and testament, any and all); passive structures, etc. Lawyers use language to demarcate their membership in the legal community, to create an aura of mystery, and to require a certain degree of education and thus block easy entry by outsiders. "The law is a profession of words" (Mellinkoff 1963, 6). In legal texts language is "the vehicle of the law" (Orts 2015, 486) carrying the legal concepts, and it is difficult for laypeople or outsiders in the legal community to understand.

One stylistic feature inherent in legal documents is its prescriptive nature. Prescriptive legal texts and deontic modality are closely connected (Williams 2007, 83). The former "are regulatory instruments containing rules of conduct or norms. Accordingly, they prescribe a specific course of action that an individual ought to conform to" (Sarcevic 1997, 11). The prescription is a variant of instruction, when any authority, social institution or legislative body becomes a source of motivation. Such prescriptions are aimed at regulating the norms of behaviour of individuals belonging to any social area. Therefore, prescriptive legal texts fall within the realm of deontic modality, which is bound up with imposing obligations, regulating and prescribing the recipient's behaviour (Gibova 2011, 7).

Modality may vary from one language to another one based on its lexical and syntactic features. This variation can create discrepancies which make the translation process challenging. For example, in their study on deontic modal language in the Polish and English versions of the Charter of Fundamental Rights of the European Union, Jaskot and Wiltos (2017) revealed irregularities at both the semantic and syntactic levels: a clear tendency to construct sentences with directly expressed modality in English, and a tendency to construct pseudo-descriptive sentences (whose modality is the result of conventionalization) in Polish. As Jaskot and Wiltos (2017, 11, 13) put it, "the lack of a clear modal functor in Polish sentences leaves ample room for possible interpretations". In her study on modality in English and Arabic, Baker (1992) revealed that English modals are grammatical, while the Arabic ones are a mixture of grammatical and lexical resources. The Arabic language possesses a richer system of lexical and grammatical means to express various nuances of modality. According to Lian and Jiang (2014, 499), in Chinese legal discourse,

the great majority of modal operators are high value modal verbs [...], while in English translation translators tend to use median and low value modal verbs, such as shall, may and should, attempting to standardize people's behavior in a relatively gentle tone rather than in an enforced way, and to avoid "the excessive abstractions and impersonality of the laws".

Russian and French also have specific systems of modality which create obstacles when translating English legal texts into these languages. The similarities and discrepancies among the English, French and Russian deontic modals used in legal discourse are studied in the present article.

\subsection{Deontic Modal Markers in English Legal Discourse}

To carry out a contrastive analysis intended to find semantic similarities and discrepancies among the English, French and Russian modal markers, Part 2.3 deals with the semantic 
functions of modal verbs shall, should and may and lexical modals have the right to and be entitled to found in the English version of the Universal Declaration of Human Rights. Other modal markers have not been considered simply because there are no occurrences of such forms in the English-language text.

\subsubsection{Shall}

As Williams $(2007,115)$ puts it, shall, that accounts for almost $23 \%$ of all finite verbal constructions, and is almost twice as common as its nearest modal rival, may, and continues to constitute one of the most characteristic features of legalese, whereas its use outside legal discourse is on the decline in favour of will. In the same vein, Cooper $(2011,6)$ who has reviewed the linguistic function of shall in contemporary English and its deontic function in Legal English, argues that the verb "has effectively faded into non-use in the general language and, as such, has become an archaism; however, its use in both private legal and legislative texts is identified as being frequent".

Due to its frequent use in English legal discourse, shall is considered to be the most misused word, seen as "none other than an archaism which causes interpretation problems for legal specialists, translators, and lay readers" (Krapivkina 2017,305), and "the biggest troublemaker" for legal experts and courts due to the lack of precision in using it in legislative texts (Wydick 1998). Triebel (2009) argues that shall is used both to express obligation and imply futurity, thus creating ambiguity. Williams $(2011,140)$ provides examples of ritualistic uses of the verb shall to express a "legalistic flavor." Bhatia $(1993,101-2)$ holds that "adherence to tokens of legalese such as shall not only sustains the myth of precision in legal language but also perpetuates a style and language that differentiates the genre from that of other professions". However, stylistic uses of shall pose "a risk to transparency in that the reader may construe them as imposing obligation where none is intended" (Foley 2002, 366).

Summarizing the results of previous research on the modal verb shall in English legal discourse (Bhatia 1993; Cooper 2011; Foley 2002; Krapivkina 2017; Williams 2007), the following core semantic functions of this deontic modal marker can be distinguished: imposing an obligation, expressing a prohibition, granting permission, and adding some flavour of the law.

\subsubsection{Should}

In contemporary English, should is the marker of "weak" necessity whose basic distinction of the markers of "strong" necessity (e.g., must, have to) is that for the latter the consequences are more severe if the obligation is not fulfilled (Smith 2003, 242). Unlike must, it implies that the speaker feels some doubt about the actualization of the situation (Declerck 1991, $378)$, and hence allows for non-actualization. As Huddleston and Pullum $(2002,186)$ put it, the deontic modal verb should "is usually subjective, indicating what the speaker considers 'right' - whether morally or as a matter of expediency". Not surprisingly, then, "the frequency of occurrence of this modal verb in prescriptive legal texts is rather low. It is uncommon in statute law, and found only in declarations, codes and regulations to express a warning not to do something or a recommendation to commit certain actions (Williams 2007). 


\subsubsection{May}

The second most commonly used modal marker in legal English is may (Williams 2007). Together with the modal verb shall, may is the only other modal verb in which usage in legal English is greater than in General English (Foley 2001, 193).

In legal discourse, may conveys two deontic meanings: permission in positive contexts and prohibition in a negative environment (Aitken and Butt 2004; Williams 2007). In Legal English, both shall and may authorize the recipient to do something. The difference lies in the fact that may implies discretion, while shall (or must) obligation (see International Labour Office 2007). The modal shall is used for the imperative, while may is a permissive verb.

\subsubsection{Be Entitled to and Have the Right to}

In English, modality is primarily associated with the central modal auxiliaries (Williams 2006, 82) or primary (will, would, shall, may, can, must) and secondary (should, might, could, would, and ought to) modals (Perkins 1983). However, modality can be also expressed by a large number of grammatically and syntactically diverse forms. These lexical modals include adjectives such as liable, obligatory or permissible, adverbs such as perhaps or surely, verbs such as allow or require, nouns such as permission or right (Huddleston and Pullum 2002, 173), participles such as bound, entitled or authorized (Perkins 1983).

Unlike other lexical modals, the expressions be entitled to and have the right to are regularly employed in legal texts. Interesting here is the distinction between be entitled to and the modal verb may drawn by the Indiana Drafting Manual (1999): the deontic past participle expression be entitled to should be used to create a right, while may should be used to create discretionary authority. This distinction seems to eliminate the ambiguity of deontic modal expressions. However, in legal texts they are often used as synonyms (Jaskot and Wiltos 2017). The same is true for the lexical modal have the right to which is employed to confer rights in the contexts where the modal verbs may and shall are used.

Taking prior research altogether, it seems possible to build up a taxonomy of core deontic modal functions found in legal texts (see Figure 1).

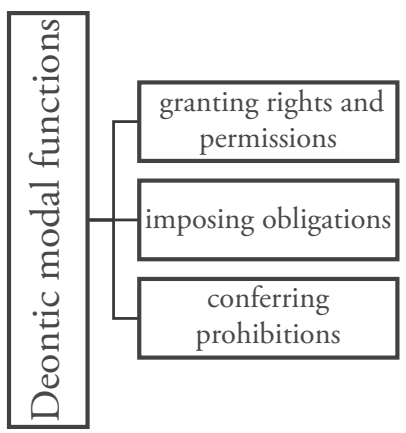

Figure 1. Core deontic modal functions in legal texts. 


\section{The Current Study}

\subsection{Materials}

The linguistic data chosen in this article comes from the Universal Declaration of Human Rights drafted by representatives with different legal and cultural backgrounds from all regions of the world. The Declaration was proclaimed by the United Nations General Assembly in Paris on 10 December 1948 as a common standard for all peoples and all nations, and it has been translated into over 500 languages, with the original language being English. The reason for choosing this document is that it contains a large amount of modal markers in the English, French and Russian versions, which can provide rich materials for this research to conduct a contrastive study.

The data consists of 134 deontic modal markers which have been examined to study how the English, French and Russian resources are employed in legal discourse and reveal what translation procedures are used to express the nuances of modality. For the analysis of deontic modality, English was chosen as a standard, and the data of the Russian and French languages were used as a contrasting background.

\subsection{Methodology}

Modal verbs occur frequently in the Universal Declaration of Human Rights, so it is not suitable for researchers to do the data collection and data analysis directly in the texts. Therefore, a small parallel corpus of English, French and Russian was constructed for data processing and analysis. The specific steps were as follows. The texts were transformed into the TXT format and Super Align software was used to align the English, French and Russia corpora.

The article used the contrastive method to approach modals' translation. Through the contrastive study among the English, French and Russian modal systems, an attempt was made to build up an analytical framework and find similarities and discrepancies between the semantic functions of modal markers in the three parallel texts.

All deontic statements found in the English, French and Russian texts were divided into three groups by the type of semantic function they perform (see Figure 1): granting rights and permissions, imposing obligations and conferring prohibitions (Foley 2001; Williams 2007). Examples of each semantic function are presented in sub-sections 4.1-4.3.

\section{Results}

\subsection{Granting Rights and Permissions}

(1) Whereas disregard and contempt for human rights have resulted in barbarous acts which have outraged the conscience of mankind, and the advent of a world in which human beings shall enjoy freedom of speech and belief and freedom from fear and want has been proclaimed as the highest aspiration of the common people

Принимая во внимание, что пренебрежение и презрение к правам человека привели к варварским актам, которые возмущают совесть 
человечества, и что создание такого мира, в котором люди будут иметь свободу слова и убеждений и будут свободны от страха и нужды, провозглашено как высокое стремление людей.

Considérant que la méconnaissance et le mépris des droits de l'homme ont conduit à des actes de barbarie qui révoltent la conscience de l'humanité et que l'avènement d'un monde où les êtres humains seront libres de parler et de croire, libérés de la terreur et de la misère, a été proclamé comme la plus haute aspiration de l'homme,

The deontic modality exhibited by the modal shall is omitted in the Russian and French renditions. Instead of shall, the translator uses the future form of the lexical verb иметь in the Russian text and the future form of the verb être in the French text. The Russian and French sentences do not contain an explicit obligation, but convey an imperative meaning of shall demonstrated by the drafter's choice.

(2) Everyone is entitled to all the rights and freedoms set forth in this Declaration, without distinction of any kind, such as race, colour, sex, language, religion, political or other opinion, national or social origin, property, birth or other status.

Каждый человек должен обладать всеми правами и всеми свободами, провозглашенными настоящей Декларацией, без какого бы то ни было различия, как-то в отношении расы, цвета кожи, пола, языка, религии, политических или иных убеждений, национального или социального происхождения, имущественного, сословного или иного положения.

Chacun peut se prévaloir de tous les droits et de toutes les libertés proclamés dans la présente Déclaration, sans distinction aucune, notamment de race, de couleur, de sexe, de langue, de religion, d'opinion politique ou de toute autre opinion, d'origine nationale ou sociale, de fortune, de naissance ou de toute autre situation.

The English modal marker be entitled to used to grant a permission is rendered with the Russian modal verb должен that conveys the imperative rather than permissive meaning. In the French text, the morphological form of the verb pouvoir conveys the permissive meaning.

(3) Everyone has the right to seek and to enjoy in other countries asylum from persecution. Каждый человек имеет право искать убежища от преследования в других странах и пользоваться этим убежищем.

Devant la persécution, toute personne a le droit de chercher asile et de bénéficier de l'asile en d'autres pays.

The modal marker have/has the right, that serves to grant a right, is translated into Russian with the modal marker иметь право and into French with the lexical modal avoir le droit which convey the similar permissive meaning as the English form.

(4) Marriage shall be entered into only with the free and full consent of the intending spouses. 
Брак может быть заключен только при свободном и полном согласии обеих вступающих в брак сторон.

Le mariage ne peut être conclu qu'avec le libre et plein consentement des futurs époux.

Permission extends to the right to contract marriage. In this example, shall is translated with the Russian modal verb может whose positive form always conveys the permissive meaning in the legal context. In the French version, the negative form of the verb pouvoir conveys the prohibitive meaning.

(5) Everyone, as a member of society, has the right to social security and is entitled to realization, through national effort and international co-operation and in accordance with the organization and resources of each State, of the economic, social and cultural rights indispensable for his dignity and the free development of his personality.

Каждый человек, как член общества, имеет право на социальное обеспечение и на осуществление необходимых для поддержания его достоинства и для свободного развития его личности прав в экономической, социальной и культурной областях через посредство национальных усилий и международного сотрудничества и $в$ соответствии со структурой и ресурсами каждого государства.

Toute personne, en tant que membre de la société, a droit à la sécurité sociale; elle est fondée à obtenir la satisfaction des droits économiques, sociaux et culturels indispensables à sa dignité et au libre développement de sa personnalité, grâce à l'effort national et à la coopération internationale, compte tenu de l'organisation et des ressources de chaque pays.

Have the right to and be entitled to are translated with the Russian modal marker - uмeem право that conveys the permissive meaning. The same strategy is used in the French version. The English modal marker is entitled to has been omitted. The meaning conveyed by this marker is rendered with the infinitive preceded by the preposition $\dot{a}$.

\subsection{Imposition of Obligations}

(6) Whereas it is essential, if man is not to be compelled to have recourse, as a last resort, to rebellion against tyranny and oppression, that human rights should be protected by the rule of law ...

принимая во внимание, что необходимо, чтобы права человека охранялись властью закона в целях обеспечения того, чтобы человек не был вынужден прибегать, в качестве последнего средства, квосстанию против тирании и угнетения;

Considérant quill est essentiel que les droits de l'homme soient protégés par un régime de droit pour que l'homme ne soit pas contraint, en suprême recours, à la révolte contre la tyrannie et l'oppression,

In this example, should is translated into Russian with the modal adverb необходимо which conveys the stronger imperative meaning than the English modal verb should. In the French 
version, should is rendered with the subjunctive soient which conveys the meaning of necessity. It is interesting to note that it is especially in international legal documents that lay down general principles rather than specific obligations that should is employed more often.

(7) They are endowed with reason and conscience and should act towards one another in a spirit of brotherhood.

Они наделены разумом и совестью и должны поступать в отношении друг друга в духе братства.

Ils sont doués de raison et de conscience et doivent agir les uns envers les autres dans un esprit de fraternité.

In the English version, there is no explicit obligation to "act towards one another in a spirit of brotherhood", merely the assertion that that action would be a great idea. In the Russian version, the deontic modal verb должны, which conveys the stronger imperative meaning than the English modal should, is used. In the French text, the modal doivent conveys the meaning of stronger obligation than should.

(8) The will of the people shall be the basis of the authority of government; this will shall be expressed in periodic and genuine elections which shall be by universal and equal suffrage and shall be held by secret vote or by equivalent free voting procedures.

Воля народа должна быть основой власти правительства; эта воля должна находить себе выражение в периодических и нефальсифицированных выборах, которые должны проводиться при всеобщем и равном избирательном праве путем тайного голосования или же посредством других равнозначных форм, обеспечивающих свободу голосования.

La volonté du peuple est le fondement de l'autorité des pouvoirs publics; cette volonté doit s'exprimer par des élections honnêtes qui doivent avoir lieu périodiquement, au suffrage universel égal et au vote secret ou suivant une procédure équivalente assurant la liberté du vote.

Shall, used to express an order and state the obligations of the government, is translated with the Russian deontic modal verb должна/ы which conveys the similar imperative meaning. In the French version, no modal marker is used. Instead, the linking verb est is employed.

(9) Parents have a prior right to choose the kind of education that shall be given to their children.

Родители имеют право приоритета в выборе вида образования для своих малолетних детей.

Les parents ont, par priorité, le droit de choisir le genre d'éducation à donner à leurs enfants.

The English modal shall, that is used to impose an obligation on national governments to give education to children, has been lost in the Russian rendering. The shift from the modal 
to non-modal form has distorted the nuance of meaning in the utterance. In the French text, instead of the modal marker, the infinitive preceded by the preposition $\grave{a}$ is employed to express obligation.

\subsection{Conferring Prohibitions}

(10) This right may not be invoked in the case of prosecutions genuinely arising from nonpolitical crimes or from acts contrary to the purposes and principles of the United Nations.

Это право не может быть использовано в случае преследования, в действительности основанного на совершении неполитического преступления, или деяния, противоречащего целям и принципам Организации Объединенных Наций.

Ce droit ne peut être invoqué dans le cas de poursuites réellement fondées sur un crime de droit commun ou sur des agissements contraires aux buts et aux principes des Nations Unies.

The negative form of the modal verb may is translated with the Russian negative form of the modal verb может and the French negative form of the modal pouvoir, which also convey the prohibitive meaning. What is interesting here is that in the French utterance only the negator $n e$ is used. As Schapansky $(2002,793)$ puts it, contrary negation, in which ne does not form a negative association with another element (e.g., pas, personne), "is not used to deny a proposition but rather used to weaken an assertion".

(11) No one shall be arbitrarily deprived of his property.

Никто не должен быть произвольно лишен своего имущества.

Nul ne peut être arbitrairement privé de sa nationalité, ni du droit de changer de nationalité

Prohibition is indicated by shall preceded by the negative indefinite pronoun in all the statements under study.

(12) No one may be compelled to belong to an association.

Никто не может быть принуждаем вступать в какую-либо ассоциацию.

Nul ne peut être obligé de faire partie d'une association.

The prohibition expressed with the modal may preceded by the negative indefinite pronoun no one is translated into Russian with the negative form of the modal verb может preceded by the negative indefinite pronoun никто. In the French version, it is expressed with the negative form of the verb pouvoir preceded by the negative pronoun $n u l$.

(13) These rights and freedoms may in no case be exercised contrary to the purposes and principles of the United Nations.

Осуществление этих прав и свобод ни в коем случае не должно противоречить целям и принципам Организации Объединенных Наций. 
Ces droits et libertés ne pourront, en aucun cas, s'exercer contrairement aux buts et aux principes des Nations Unies.

The prohibition expressed with the modal verb may followed by the adverb in no case is translated with the Russian negative form of the modal verb должен preceded by the adverb ни в коем случае. In the French text, the negative form of the future tense verb pouvoir followed by the adverb en aucun cas is used which indicates the omission of the modal meaning.

The distributions of deontic modal markers in the English, Russian and French texts are depicted in Tables 1, 2 and 3.

TABLE 1. The distribution of deontic modal markers in the English version.

\begin{tabular}{|c|c|c|c|c|c|c|c|c|c|}
\hline \multicolumn{2}{|c|}{ shall } & \multicolumn{2}{c|}{ Should } & \multicolumn{2}{c|}{ may } & \multicolumn{2}{c|}{ be entitled to } & \multicolumn{2}{c|}{$\begin{array}{c}\text { have } \\
\text { the right to }\end{array}$} \\
\hline Number & $\%$ & Number & $\%$ & Number & $\%$ & Number & $\%$ & Number & $\%$ \\
\hline 27 & 41 & 2 & 3 & 4 & 6 & 9 & 14 & 24 & 36 \\
\hline
\end{tabular}

TABLE 2. The distribution of deontic modal markers in the Russian version.

\begin{tabular}{|c|c|c|c|c|c|c|c|}
\hline \multicolumn{2}{|c|}{ должен } & \multicolumn{2}{c|}{ иметь право } & \multicolumn{2}{c|}{ мочь } & \multicolumn{2}{c|}{ необходимо } \\
\hline Number & $\%$ & Number & $\%$ & Number & $\%$ & Number & $\%$ \\
\hline 21 & 26 & 28 & 35 & 30 & 36.8 & 2 & 0.2 \\
\hline
\end{tabular}

TABLE 3. The distribution of deontic modal markers in the French version.

\begin{tabular}{|c|c|c|c|c|c|c|c|}
\hline \multicolumn{2}{|c|}{ pouvoir } & \multicolumn{2}{c|}{ devoir } & \multicolumn{2}{c|}{ avoir le droit } & \multicolumn{2}{c|}{$\grave{a}+$ infinitive } \\
\hline Number & $\%$ & Number & $\%$ & Number & $\%$ & Number & $\%$ \\
\hline 9 & 30 & 8 & 26.6 & 11 & 36.7 & 3 & 10 \\
\hline
\end{tabular}

The distributions of positive and negative forms of deontic modals in the English, Russian and French texts are presented in Tables 4, 5 and 6.

TABLE 4. The distribution of positive and negative deontic modal markers in the English text.

\begin{tabular}{|l|c|c|c|}
\hline & Shall & Should & May \\
\hline Positive form & 17 & 2 & 0 \\
\hline Negative form & 10 & 0 & 4 \\
\hline
\end{tabular}

TABLE 5. The distribution of positive and negative deontic modal markers in the Russian text.

\begin{tabular}{|l|c|c|}
\hline & $\begin{array}{c}\text { Должен/ } \\
\text { должны }\end{array}$ & $\begin{array}{c}\text { Может/ } \\
\text { могут }\end{array}$ \\
\hline Positive form & 4 & 2 \\
\hline Negative form & 5 & 8 \\
\hline
\end{tabular}


TABLE 6. The distribution of positive and negative deontic modal markers in the French text.

\begin{tabular}{|c|c|c|}
\hline & Pouvoir & Devoir \\
\hline Positive form & 0 & 8 \\
\hline Negative form & 9 & 0 \\
\hline
\end{tabular}

The distribution of the modal verbs in active and passive sentences is presented in Table 7.

TABLE 7. The distribution of the modal verbs shall, should and may and their Russian and French equivalents in active and passive sentences.

\begin{tabular}{|c|c|c|}
\hline & Active & Passive \\
\hline English modals & 9 & 24 \\
\hline $\begin{array}{c}\text { Russian modal } \\
\text { equivalents }\end{array}$ & 16 & 14 \\
\hline $\begin{array}{c}\text { French modal } \\
\text { equivalents }\end{array}$ & 21 & 17 \\
\hline
\end{tabular}

Table 8 presents the results of a contrastive analysis of the deontic modal markers in the parallel texts at the semantic level (see Table 8).

TABLE 8. English, Russian and French modal markers: results of the contrastive analysis.

\begin{tabular}{|l|l|l|}
\hline English & Russian & French \\
\hline \multirow{3}{*}{ shall } & может & pouvoir \\
\cline { 2 - 3 } & должен & être in present simple \\
\cline { 2 - 3 } & omitted & omitted \\
\hline \multirow{3}{*}{ should } & future tense & être in future simple \\
\hline \multirow{2}{*}{ may (in no case) } & & devoir \\
\hline & (ни в коем случаем не) должно & $\begin{array}{l}\text { (ne) pouvoir in present } \\
\text { subjunctive }\end{array}$ \\
\hline & должен & être in present subjunctive \\
\cline { 2 - 3 } have the right to & иеободимо (adverb) & devoir \\
\hline \multirow{2}{*}{ be entitled to } & должен & avoir le droit \\
\cline { 2 - 3 } & имеет право & pouvoir \\
\hline
\end{tabular}

\section{Discussion}

As Tables 1, 2 and 3 show, there is a marked variation in the distribution of deontic modal markers in the English, Russian and French texts. The tables show the predominance of the modals shall and have the right to in the English text, может and имеет право in the Russian one, and pouvoir and avoir le droit in the French version. It should be noted that Russian and French have fewer modal verbs than English. For example, French has only two modal verbs that convey the deontic meanings, pouvoir and devoir. In Russian, these 
are должен and мочь. In this regard, the deontic meanings are often conveyed by lexical modal markers, the most common of which are avoir le droi in the French version $(36.7 \%$ of all occurrences of modal markers in the French text) and иметь право in the Russian one (35\% of all occurrences of modal markers in the Russian text).

As for English, the observed greater frequency of shall, comprising $41 \%$, is consistent with the previous results (Bázlik and Ambrus 2009; Cooper 2011; Krapivkina 2017; Tiersma 1999). Even when taking into account the small size of the corpus, it seems possible to say that the modal verb shall is the most commonly used modal in Legal English, with the second ranked have the right to, comprising $36 \%$ of all occurrences. The non-frequent occurrence of should (3\%) is quite understandable, because it conveys weak obligation. It may come as a surprise, however, that must is not in the text. This might be due to the increased use of shall to express strong obligation, and the negative form of may to express prohibition.

Table 4 shows the predominance of positive forms of shall and should and the predominance of negative forms of may in the English text. In the Russian text, as can be seen in Table 5, the modal verbs должен and может in the negative environment are predominant. Table 6 shows that in the French version, the modal verb pouvoir is used only in its negative form, whereas the verb devoir in its positive form.

In the English text, negation is mainly expressed with the negative pronoun no one followed by the positive form of the modal verb. The following examples illustrate the case:

(14) No one shall be arbitrarily deprived of his property.

No one may be compelled to belong to an association.

The Russian equivalent is the indefinite pronoun никто followed by the negative particle не and the modal verb:

(15) Никто не должен быть произвольно лишен своего имущества.

Никто не может быть принуждаем вступать в какую-либо ассоциацию.

The French equivalent of the English pronoun no one is nul followed by the negative particle ne.

(16) Nul ne peut être arbitrairement privé de sa nationalité, ni du droit de changer de nationalité.

Unlike the English drafter, the Russian and French ones intend the negative concord interpretation, on which the Russian word никто and the French word nul do not exert independent negative force (Thornton et al. 2016).

Table 7 shows that the voice of sentences containing modal verbs does not always coincide in the three parallel texts. The analysis has identified five cases of discrepancy in the English, Russian and French texts. This observation is consistent with the features of English, Russian and French legal languages in general, as the passive voice is used to a lesser extent in legal French and Russian (Kozhevnikov 2016; Krapivkina 2018). The following are examples from the parallel texts. 
(17) this will shall be expressed in periodic and genuine elections ...

эта воля должна находить себе выражение в периодических и
нефальсифицированных выборах ... cette volonté doit s'exprimer par des élections honnêtes ...

In the English sentence, the modal verb is used in its passive form, whereas in the French and Russian versions the modal verbs are in their active forms followed by the reflexive verbs.

A greater diversity of modal verbs was revealed in the English text. One and the same English modal marker has two or more versions in the Russian and French texts. The carrier of modal meaning in Russian and French sentences is a verb in both the active and passive voices. The analysis identified that the frequency of using "modal verb + expansion form" in the passive form is much higher in the English text. In the Russian and French texts, a tendency to use the active voice of reflexive verbs after the modal markers was observed.

There are certain shifts within the modal verbs observed in the parallel texts. In order to express prohibition, the negative forms of the modal verbs должен and может are used in the Russian text, while in the English text negated forms of the verbs shall and may are used. In the French text, the negative form of the modal verb pouvoir is used. There is no strict correspondence between these forms. English negated forms can be expressed both with the Russian verbs не должен and не может. In the French version, the negative forms of the verbs être in future simple and pouvoir in present simple are used. In these cases, the Russian and French languages do not differentiate these meanings. Both modal markers are valid due to the general regulatory nature of declarations that eliminates differences in the meanings of modal verbs. This is an example of how extralinguistic factors influence the rethinking of grammatical forms and lexical units.

The English modal verbs shall and should are rendered into Russian with the verb должен, thus being considered synonyms. The same is observed in the French version: shall and should are rendered with the verb devoir. However, the modal verb should is not comparable to shall in its deontic strength. It is rarely observed as an illocutionary force indicator of directives, which might be due to the weakness with which obligation is expressed.

The analysis has revealed one occurrence of the adverb необходимо for rendering the English should in the Russian text. This rendering changed the simple syntactic structure of the English sentence into the complex one in the Russian text. Shall has proved to be semantically equivalent to the Russian verbs может and должен. It is translated into Russian with должен and может, and conveys the directive or permissive meaning when its purpose is to regulate human behaviour. Additionally, the Russian simple future and the English modal shall have proved to be technically equivalent in conveying the meaning of shall. In this case, the Russian sentence does not contain explicit obligation, but conveys the imperative meaning of shall. The zero equivalent strategy, which is employed in one instance for shall, is inadequate since the nuances of modality are lost. 
In the French version, five variants of rendition of the verb shall were found: the present and future tense of the verb être, the modal verbs pouvoir and devoir, and omission of modal markers.

The modal marker be entitled to has two meanings in the Russian text: permission and obligation. The same is observed in the French text. It is rendered with two modal markers: avoir le droit and pouvoir. Only the modal marker have the right to has one correspondence in the Russian and French texts.

Thus, two types of translation strategies were identified in the Russian and French texts: formal and semantic equivalence; and formal mismatch but semantic equivalence. Below are examples of the use of these strategies.

(18) Men and women of full age, without any limitation due to race, nationality or religion, have the right to marry and to found a family.

Мужчины и женщины, достигшие совершеннолетия, имеют право без всяких ограничений по признаку расы, национальности или религии вступать в брак и основывать свою семью.

A partir de l'âge nubile, l'homme et la femme, sans aucune restriction quant à la race, la nationalité ou la religion, ont le droit de se marier et de fonder une famille.

The translation corresponds to the source text both formally and semantically.

(19) These rights and freedoms may in no case be exercised contrary to the purposes and principles of the United Nations.

Осуществление этих прав и свобод ни в коем случае не долюно противоречить целям и принципам Организации Объединенных Наций.

Ces droits et libertés ne pourront, en aucun cas, s'exercer contrairement aux buts et aux principes des Nations Unies.

The negative form of the modal may means it is prohibited. In the Russian text, the translator uses the negative form of the verb должно which also means it is prohibited. It corresponds to the original text semantically, but not formally. In the French text, the negative form of the English modal verb may be rendered with the negative subjunctive pouvoir, which conveys the same prohibitive meaning.

\section{Concluding Remarks}

This study has attempted to offer an account of deontic modal markers across the English, Russian and French versions of the Universal Declaration of Human Rights. The main objective of this article has been to detect key modality features and linguistic means that convey deontic modal meanings by examining the three parallel texts from the perspective of a contrastive analysis. 
The need to study deontic modality has arisen due to semantic discrepancies between modal expressions in linguistic variants of the same text. The negotiation of such semantic difficulties is a challenge for legal translators.

In the English, Russian and French legal texts, deontic modality performs a variety of functions, including granting rights and permissions, imposing obligations, and conferring prohibitions. A variety of modal markers are employed to perform these functions.

Despite the fact that Russian and French modality systems are not as grammaticalized as the English one, Russian and French prove to possess a number of deontic modal markers which enhance the stylistic variation. In Russian, the modal markers found in the text under study are the modal verbs должен and мочь, the modal adverb необходимо and the modal construction иметь право. In French, these are the modal verbs devoir and pouvoir and the lexical modal expressions avoir le droit and infinitive $+\grave{a}$.

The analysis aimed to identify convergences and discrepancies in the use of deontic linguistic means has revealed that French and Russian have more in common than French and English or Russian and English. Translators should properly understand the modal systems of source and target languages and distinctions that each modal displays due to the ambiguity manifested by modal verbs, which can be polysemous and get a precise meaning only in context.

The present study has offered only a glimpse into this problem by looking at some instances of semantic discrepancies between the three languages. Further studies of authentic data derived from various text types are needed. One of the avenues for further research is a context that plays a key role in the rendering of modals across languages.

\section{References}

Aitken, James K., and Peter Butt. The Elements of Drafting. Sydney: Lawbook.

Baker, Mona. 1992. In Other Words. London: Routledge.

Bhatia, Aditi, and Vijay K. Bhatia. 2011. "Discursive Illusions in Legislative Discourse: A Socio-Pragmatic Study." International Journal for the Semiotics of Law - Revue internationale de Sémiotique juridique 24 (1): 1-19. https://doi.org/10.1007/s11196-010-9178-5.

Bhatia, Vijay. 1993. Analysing Genre: Language Use in Professional Settings. London: Longman.

Boginskaya, Olga. 2020. "The Simplification of Jury Instructions: Legal-Lay Interactions in Jury Trials." ESP Today 8 (2): 297-318.

Bybee, Joan, Revere Perkins, and William Pagliuca. 1994. The Evolution of Grammar: Tense, Aspect, and Modality in the Languages of the World. Chicago: University of Chicago Press.

Cooper, Paul Kendall. 2011. Is There a Case for the Abolition of Shall from EU Legislation? Riga: Riga Graduate School of Law.

Declerck, Renaat 1991. A Comprehensive Descriptive Grammar of English. Tokyo: Kaitakusha.

Depraetere, Ilse, and Chad Langford. 2020. Advanced English Grammar: A Linguistic Approach. London: Bloomsbury Academic.

Dickerson, Reed. 1990. "Choosing between Shall and Must in Legal Drafting." Scribes. Journal of Legal Drafting 1: 144-47.

Downing, Angela, and Phillip Locke. 1992. A University Course in English Grammar. Hemel Hempstead: Phonix ELT. 
Foley, Richard. 2001. "Going Out of Style? Shall in EU Legal English.” Proceedings of the Corpus Linguistics 2001 Conference, edited by P. Rayson, A. Wilson, T. McEnery, A Hardie, and S. Khoja, 185-95.

Lancaster: University Centre for Computer Corpus Research on Language Technical Papers.

—. 2002. "Legislative Language in the EU: The Crucible." International Journal for the Semiotics of Law 15

(4): 361-74. https://doi.org/10.1023/A:1021203529151.

Garner, Bryan. 1995. A Dictionary of Modern Legal Usage. New York: Oxford University Press.

Gibova, Klaudia. 2011. "On Modality in EU Institutional-Legal Documents." In English Matters II, edited by Alena Kačmárová, 6-12. Prešove: Prešovská univerzita.

Halliday, Michael. 1978. Language as Social Semiotic: The Social Interpretation of Language and Meaning. Theory \& Practice in Language Studies. London: Edward Arnold.

Huddleston, Rodney, and Geoffrey K. Pullum. 2002. The Cambridge Grammar of the English Language. Cambridge: Cambridge University Press.

International Labour Office. 2007. Manual for Drafting ILO Instruments. The Quick Guide. Geneva International Labour Organization. https://www.ilo.org/wcmsp5/groups/public/@dgreports/@jur /documents/publication/wcms_426014.pdf.

Jaskot, Maciej Paweł, and Agnieszka Wiltos. 2017. "An Approach to the Translation of Deontic Modality in Legal Texts. The Case of the Polish and English Versions of the Charter of Fundamental Rights of the European Union." Cognitive Studies 17: 12-34. https://doi.org/10.11649/cs.1454.

Kozhevnikov, Vladimir. 2016. Techniques in Creating Legal Documents. Omsk: Omsk Institute of Economics.

Krapivkina, Olga. 2017. "Semantics of the Verb Shall in Legal Discourse." Jezikoslovlje 18 (2): 305-17.

- 2018. "Sight Translation and Its Status in Training of Interpreters and Translators." Indonesian Journal of Applied Linguistics 7 (3): 695-704. https://doi.org/10.17509/ijal.v7i3.9820.

Lian, Zhangjun, and Ting Jiang. 2014. "A Study of Modality System in Chinese-English Legal Translation from the Perspective of SFG." Theory and Practice in Language Studies 4 (3): 497-503. https:// doi.org/10.4304/tpls.4.3.497-503.

Lyons, John. 1977. Semantics. Cambridge: Cambridge University Press.

Mattila, Heikki E.S. 2013. Comparative Legal Linguistics. Language of Law, Latin and Modern Lingua Francas. London: Routledge.

Mellinkoff, David. 1963. The Language of the Law. Boston: Little, Brown \& Co.

Orts, María Ángeles. 2015. "Power and Complexity in Legal Genres: Unveiling Insurance Policies and Arbitration Rules." International Journal for the Semiotics of Law - Revue internationale de Sémiotique juridique 28 (3): 485-505. https://doi.org/10.1007/s11196-015-9429-6.

Palmer, Frank. 2001. Mood and Modality. Cambridge: Cambridge University Press.

—. 2003. "Modality in English: Theoretical, Descriptive and Typological Issues." In Modality in

Contemporary English, edited by Roberta Facchinetti, Frank Palmer, and Manfred Krug, 1-17. Berlin: Mouton de Gruyter. https://doi.org/10.1515/9783110895339.1.

-. 2013. Modality and the English Modals. 2nd ed. New York: Routledge.

Panocová, Renáta, and Lukáš Lukačín. 2019. "Epistemic Modal Markers in Two Domains of Academic Research Papers in English.” Brno Studies in English 45 (2): 121-38.

Parrott, Martin. 2000. Grammar for English Language Teachers. Cambridge: Cambridge University Press.

Perkins, Michael R. 1983. Modal Expressions in English. London: Frances Pinter.

Quirk, Randolph, Greenbaum Sidney, Leech Geoffrey, and Svartvik Jan. 1989. A Comprehensive Grammar of the English Language. Harlow: Longman.

Sarcevic, Susan. 1997. New Approach to Legal Translation. The Hague: Kluwer Law International.

Smith, Nicholas. 2003. "Changes in the Modals and Semi-Modals of Strong Obligation and Epistemic Necessity in Recent British." In Modality in Contemporary English, edited by Roberta Facchinetti, Frank Palmer, and Manfred Krug, 241-66. Berlin: Mouton de Gruyter. https://doi.org/10.1515 /9783110895339.241.

Thornton, Rosalind, Anna Notley, Vincenzo Moscati, and Stephen Crain. 2016. "Two Negations for the Price of One.” Glossa: A Journal of General Linguistics 1 (1): 45. https://doi.org/10.5334/gigl.4.

Tiersma, Peter. 1999. Legal Language. Chicago: University of Chicago Press. 
Triebel, Volker. 2009. "Pitfalls of English as a Contract Language." In Translation Issues in Language and Law, edited by Frances Olsen, Alexander Lorz, and Dieter Stein, 147-81. London: Palgrave Macmillan. https://doi.org/10.1057/9780230233744_10.

Trosborg, Anna. 1997. Rhetorical Strategies in Legal Language. Germany: Gunter Narr Verlag Tübingen.

Williams, Christopher. 2007. Tradition and Change in Legal English: Verbal Constructions in Prescriptive Texts. Bern: Peter Lang.

—. 2011."Legal English and Plain English: An Update." ESP Across Cultures 8: 139-51.

Wydick, Richard C. 1998. Plain English for Lawyers. 4th ed. Durham: Carolina Academic Press. 